\title{
Penerapan Model Problem Based Learning dalam Meningkatkan Kemampuan Menganalisis Materi Kesetaraan Berat Benda Kelas 2
}

\author{
Nila Novita Sari \\ Universitas Sebelas Maret \\ nilanovitasari@student.uns.ac.id
}

\section{Article History}

received 30/4/2021

revised 30/5/2021

accepted 30/6/2021

\begin{abstract}
The research's purpose was to improve the analytical skill of 2nd primary students according to equal weight material by Problem Based Learning model. This action research consists of two cycles which has two meetings. The stages are planning, implementing, observing, and reflection. The subject of research was 2-year students in SDN Somomorodukuh 1 academic year 2020/2021, consist of 19 students. Data collection was based on the interview, observation and test. Data analysis components (Interactive Model) by Miles-Huberman was used in this research. From pre cycle achievement 73,69\% (14 students) wasn't finish KKM. From cycle I only 63,15\% (12 students) completed the KKM. In Cycle II, students who completed KKM increase into 17 (89,47\%). The data was met the research indicator and the cycle was stopped. As a result of this research, equal weight material according to 2-year primary students in SD Somomorodukuh 1 were improved by Problem Based Learning model.
\end{abstract}

Keywords: Analytical Skill, PBL, Mathematics, Equal Weight

\begin{abstract}
Abstrak
Penelitian bertujuan untuk meningkatkan kemampuan menganalisis siswa kelas 2 pada materi kesetaraan berat benda meggunakan model Problem Based Learning. Penelitian ini merupakan penelitian tindakan kelas dengan dua siklus yang setiap siklusnya terdiri dari dua pertemuan.Tahapan dari tiap siklusnya adalah perencanaan, pelaksanaan, observasi, dan refleksi. Subjek penelitian ini adalah siswa kelas 2 SDN Somomorodukuh 1 tahun ajaran 2020/2021 yang berjumlah 19 siswa. Teknik pengumpulan data berupa wawancara, observasi dan tes. Analisis data yang digunakan adalah model analisis interaktif Miles-Huberman. Dari hasil Prasiklus 73,69 \% (14 siswa) tidak memenuhi KKM. Pada siklus I siswa yang mencapai KKM hanya 63,15\% (12 siswa). Pada siklus II siswa yang mencapai KKM meningkat menjadi 17 siswa dengan persentase $89,47 \%$ sudah memenuhi indikator penelitian sehingga siklus dihentikan. Berdasarkan hasil penelitian dapat disimpulkan bahwa kemampuan menganalisis pada materi kesetaraan berat benda pada siswa kelas 2 siswa SD Somomorodukuh 1 dapat ditingkatkan melalui penggunaan model pembelajaran Problem Based Learning.
\end{abstract}

Kata kunci: Kemampuan Menganalisis, PBL, Matematika, Kesetaraan Berat 


\section{PENDAHULUAN}

Pendidikan erat kaitannya dengan pembentukan karakter siswa yang berakhlak mulia, cerdas dan bertanggung jawab. Untuk mendukung tujuan pendidikan nasional maka proses pembelajaran pada pendidikan dasar seperti yang disebutkan dalam Peraturan Menteri Pendidikan dan Kebudayaan Nomor 24 tahun 2016 Tentang Kompetensi Dasar pada kurikulum 2013 berisi kemampuan dan materi pembelajaran untuk suatu mata pelajaran pada masing-masing satuan pendidikan yang mengacu pada kompetensi inti. Menurut Suwangsih \& Tiurlina (2018:2), kompetensi tersebut diperlukan agar siswa dapat memiliki kemampuan memperoleh, mengelola, dan memanfaatkan informasi untuk bertahan hidup pada keadaan yang selalu berubah, tidak pasti, dan kompetitif. Salah satu muatan pembelajaran yang terdapat pada kurikulum 2013 adalah matematika. Oleh karena itu, dari mulai pendidikan usia dini yang biasa dikenal dengan PAUD, sekolah dasar, sampai perguruan tinggi pun selalu melibatkan matematika pada mata pelajaran yang wajib.

Pelaksanaan pembelajaran matematika sekolah dasar harus dilakukan secara bertahap dan saling terkait dengan muatan pembelajaran lain. Hal tersebut merupakan ciri khas pembelajaran tematik kurikulum 2013. Dalam pembelajaran siswa juga harus memiliki kemampuan kognitif, emosional, dan psikomotorik. Dalam taksonomi Bloom yang direvisi, kemampuan kognitif siswa adalah menganalisis, mengevaluasi, dan membuat keterkaitan dengan pemikiran tingkat tinggi (HOTS). Hal ini menunjukkan bahwa kemampuan analitis merupakan salah satu jenis kemampuan yang perlu ditumbuh kembangkan. Sebagai mata pelajaran, matematika merupakan salah satu jenis pembelajaran yang membutuhkan kemampuan analisis yang baik sebagai landasan pengetahuan yang dibutuhkan oleh siswa.

Menurut Ismiyati (2016:2), pengalaman yang diperoleh dari pemecahan masalah memungkinkan pengembangan keunggulan muatan matematika termasuk keterampilan membaca dan menganalisis. Kemampuan analitis memberikan bimbingan kepada siswa untuk menganalisis hubungan antara setiap informasi. Selain itu, dalam kegiatan membandingkan informasi yang ada ditinjau dari kemampuan analisisnya, memudahkan siswa untuk merangkum informasi yang diterima dalam bentuk kesimpulan. Namun, masih terdapat masalah dalam matematika. Hal ini membuktikan bahwa tujuan pembelajaran yang diharapkan belum tercapai. Untuk mencapai tujuan pembelajaran yang diharapkan, guru dan siswa harus berperan aktif dalam proses pembelajaran.

Berdasarkan observasi dan wawancara yang telah peneliti lakukan pada tanggal 4 Januari 2021 pada guru kelas dan siswa kelas II SDN Somomorodukuh 1. Hal tersebut dibuktikan dengan hasil tes pratindakan, terdapat sekitar $73.69 \%$ atau 14 siswa dari 19 siswa kemampuan menganalisisnya rendah, khususnya pada materi kesetaraan berat benda yang disajikan dalam soal cerita sehingga nilai siswa masih berada di bawah KKM yang ditentukan oleh satuan pendidikan. Secara lebih rinci, faktor-faktor yang menyebabkan rendahnya kemampuan menganalisis soal cerita pada materi berat benda pada siswa kelas II SD Somomorodukuh 1 Kecamatan Plupuh yaitu model pembelajaran yang dipakai oleh guru kurang inovatif sehingga pembelajaran terpusat pada guru. Hal tersebut menyebabkan siswa pasif. Siswa juga merasa kesulitan menganalisis soal cerita, hal tersebut mengakibatkan hasil belajar siswa pada muatan matematilka masih rendah

Berdasarkan hal-hal tersebut, dapat disimpulkan bahwa penyebab utama kemampuan menganalisis yang rendah pada siswa kelas II SDN Somomorodukuh 1 Kecamatan Plupuh adalah model pembelajaran yang digunakan kurang inovatif sehingga mengakibatkan kurangnya kemampuan menganalisis siswa. Jika tidak ada tindak lanjut dalam menangani masalah yang ada, maka tujuan pembelajaran tidak tercapai. Oleh sebab itu, perlu solusi untuk mengatasi permasalahan rendahnya kemampuan menganalisis siswa yaitu dengan menggunakan model pembelajaran 
berbasis masalah. Salah satu model pembelajaran berbasis masalah yang dapat diterapkan yaitu Problem Based Learning. Suprihatiningrum (2014:216), mengemukakan bahwa hakikatnya pembelajaran berbasis masalah menekankan pada aktivitas pemecahan masalah dalam pembelajaran. Penerapan model pembelajaran berbasis masalah merupakan salah satu pilihan yang tepat bagi siswa, karena seluruh siswa dapat berperan aktif dalam pembelajaran.

Problem Based Learning merupakan model pembelajaran bercirikan adanya permasalahan nyata sebagai konteks untuk para siswa belajar berpikir nyata dan keterampilan memecahkan masalah serta memperoleh pengetahuan. Hal tersebut didukung dengan penelitian yang dilakukan oleh Padmavathy dkk. (2013:45) hasil penelitian menunjukan bahwa pembelajaran berbasis masalah memiliki efek dalam mengajar matematika dan meningkatkan pemahaman siswa, kemampuan untuk menggunakan konsep dalam kehidupan nyata. Dalam hal ini, kemampuan analitis perlu dikembangkan, karena dapat melatih siswa untuk berpikir kritis saat menghadapi suatu masalah.

Penelitian lain dilakukan oleh Rahmadani (2017:249), yang hasil penelitiannya menunjukkan bahwa peningkatan aktivitas belajar matematika dapat diupayakan melalui pendekatan Problem Based Learning siswa kelas 4 SDN Petirejo Kecamatan Ngadirejo semester 2 tahun 2017 terbukti meningkat. Hal tersebut sesuai dengan kelebihan model Problem Based Learning (Shoimin, 2014:132), yang menyebutkan bahwa PBL dapat mendorong siswa memecahkan permasalahan dunia nyata dan membangun pengetahuannya sendiri melalui aktivitas belajarnya sehingga pembelajaran terpusat pada siswa (Student centered).

Berdasarkan pemaparan diatas, penelitian ini bertujuan untuk dapat meningkatkan kemampuan menganalisis siswa kelas 2 SDN Somomorodukuh 1 Kecamatan Plupuh tahun 2020/2021 pada aspek kognitif. Melalui peningkatan kemampuan menganalisis materi kesetaraan berat benda maka penelitian ini dapat menjadi referensi dalam upaya meningkatkan pembelajaran untuk penelitian selanjutnya.

\section{METODE}

Penelitian ini merupakan penelitian tindakan kelas (Action Research Design). Subjek penelitian ini adalah siswa kelas 2 SD Negeri Somomorodukuh 1 kecamatan Plupuh pada tahun ajaran 2020/2021 yang berjumlah 19 siswa terdiri dari 9 siswa lakilaki dan 10 siswa perempuan. Teknik pengumpulan data melalui wawancara, observasi dan tes. Analisis data yang digunakan adalah model analisis interaktif MilesHuberman. Kegiatan dalam penelitian ini yaitu mengumpulkan data (data collection), mereduksi data (data reduction), menyajikan data (data display), dan menarik kesimpulan (conclusion drawing). Penelitian ini terdiri dari dua siklus, setiap siklusnya terdiri dari dua pertemuan. Apabila satu siklus belum menunjukkan tanda-tanda perubahan ke arah perbaikan (peningkatan mutu), kegiatan riset dilanjutkan pada siklus kedua, dan seterusnya. Setiap siklus terdiri dari perencanaan, pelaksanaan tindakan, observasi, dan refleksi dengan alokasi waktu 2 × 35 menit. Indikator kinerja dalam penelitian ini adalah meningkatnya kemampuan menganalisis siswa kelas II pada materi kesetaraan berat benda. Indikator keberhasilan kinerja penelitian berdasarkan kriteria nilai dengan ketuntasan klasikal $85 \%$.

\section{HASIL DAN PEMBAHASAN}

Berikut adalah hasil pratindakan di sekolah dan siswa kelas II Sekolah Dasar Negeri Somomorodukuh 1 Kecamatan tema merawat hewan dan tumbuhan subtema hewan di sekitarku muatan pelajaran matematika materi berat. 
Tabel 1. Hasil Tes Pratindakan

\begin{tabular}{lcc}
\multicolumn{1}{c}{ Ketuntasan Belajar } & Jumlah Siswa & Persentase \\
\hline Tuntas KKM & 5 & $26,31 \%$ \\
Belum Tuntas KKM & 14 & $73,69 \%$ \\
\hline Jumlah & 19 & $100 \%$
\end{tabular}

Berdasarkan tabel 1 hasil belajar aspek pengetahuan dari tes refleksi awal masih rendah. Hal tersebut terlihat dari hasil belajar dari 19 siswa, hanya terdapat 5 siswa atau $26,31 \%$ yang sudah mencapai KKM sedangkan yang belum mencapai KKM 14 siswa atau 73,69 \%. Setelah peneliti menerapkan model pembelajaran Problem Based Learning pada materi kesetaraan berat benda pada siklus I hasil nilai kemampuan menganalisis siswa menunjukkan peningkatan jika dibandingkan dengan hasil tes pratindakan. Hasil nilai kemampuan menganalisis materi kesetaraan berat benda siklus I pada kelas 2 SD Somomorodukuh 1 sebagai berikut.

Tabel 2. Hasil Penilaian Kemampuan Menganalisis Siklus I

\begin{tabular}{llcc}
\hline \multirow{2}{*}{ No } & \multirow{2}{*}{ Keterangan } & \multicolumn{2}{c}{ Siklus I } \\
\cline { 2 - 4 } & & Pertemuan 1 & Pertemuan 2 \\
\hline 1 & Rata-Rata Nilai & 60.52 & 65.78 \\
2 & Nilai Paling Tinggi & 80 & 80 \\
3 & Nilai Paling Rendah & 30 & 50 \\
4 & Ketercapaian (\%) & 36,84 & 52,63 \\
\hline
\end{tabular}

Dari siklus I terlihat nilai siswa sudah mengalami peningkatan dibandingkan dengan hasil pratindakan. Hal tersebut terlihat dari tabel 2 hasil penilaian kemampuan menganalisis siklus I pertemuan 1 hanya $36,84 \%$ siswa yang mencapai KKM kemudian meningkat pada pertemuan 2 menjadi 52,63 \%. Adapun perolehan akhir siklus I siswa yang mencapai nilai tuntas hanya sebesar $63,15 \%$ atau 12 siswa yang tuntas KKM dan jumlah siswa yang belum tuntas KKM sejumlah 7 siswa dengan presentase $36,85 \%$. Data yang diperoleh tersebut belum menunjukkan ketercapaian indikator kerja penelitian yaitu $85 \%$. Penelitian dilanjutkan pada siklus II. Pada siklus II terjadi peningkatan pada kemampuan menganalisis pada siswa kelas II materi kesetaraan berat benda pada tema merawat hewan dan tumbuhan. Data disajikan dalam tabel berikut

Tabel 3 Siklus Hasil Penilaian Kemampuan Menganalisis Siklus II

\begin{tabular}{llcc}
\hline \multirow{2}{*}{ No } & \multirow{2}{*}{ Keterangan } & \multicolumn{2}{c}{ Siklus II } \\
\cline { 3 - 4 } & & Pertemuan 1 & Pertemuan 2 \\
\hline 1 & Rata-Rata Nilai & 73.16 & 81.57 \\
2 & Nilai Paling Tinggi & 90 & 100 \\
3 & Nilai Paling Rendah & 60 & 60 \\
4 & Ketercapaian (\%) & 73,68 & 89,47 \\
\hline
\end{tabular}

Dari tabel 3 dapat dijelaskan bahwa pembelajaran matematika dengan model pembelajaran Problem Based Learning pada materi kesetaran berat benda dapat meningkatkan kemampuan menganalisis siswa yang ditunjukkan dengan meningkatnya hasil belajar siswa. Terdapat peningkatan kemampuan menganalisis pada materi kesetaraan berat benda jika dibandingkan dengan kondisi awal dan siklus 
I kemudian meningkat lagi pada siklus II. Data dari siklus II pembelajaran 1 terlihat bahwa ketercapaian ketuntasan KKM siswa mencapai 73,68\%, yang meningkat menjadi $89,47 \%$ pada pertemuan 2. Dengan membandingkan hasil belajar kognitif tiap siswa dengan KKM yang telah ditentukan tersebut perolehan akhir siklus II diketahui, siswa yang mendapat nilai rata-rata pertemuan 1 dan 2 pada siklus II siswa yang tuntas KKM sebanyak 17 siswa dengan presentase $89,47 \%$ dan siswa yang belum tuntas KKM sebanyak 2 siswa dengan presentase 10,53\%. Jika dibandingkan dengan presentase kriteria ketuntasan belajar klasikal yang ditentukan yaitu $85 \%$ dari jumlah siswa, penelitian di siklus II ini sudah memenuhi kriteria ketuntasan belajar klasikal yang ditentukan sehingga penelitian dihentikan pada siklus II karena indikator kinerja penelitian sudah tercapai.

Hal tersebut relevan dengan penelitian sebelumnya yang dilakukan oleh Eismawati dkk. (2019) yang menunjukkan adanya peningkatan hasil belajar matematika siswa setelah diterapkannya model pembelajaran Problem Based Learning. Selain meningkatnya hasil belajar Model Problem based learning juga dapat meningkatkan kemampuan pemecahan masalah pada muatan matematika. Hal tersebut di dukung oleh penelitian dari Gunantara dkk. (2014) yang menunjukan bahwa penerapan model pembelajaran Problem Based learning (PBL) dapat meningkatkan kemampuan pemecahan masalah pada mata pelajaran Matematika.

Dengan adanya peningkatan dari hasil pratindakan, siklus I dan siklus II membuktikan bahwa model pembelajaran Problem Based Learning dapat meningkatkan kemampuan menganalisis siswa kelas II SD Somomorodukuh 1. Berdasarkan Arends (2008), Problem Based Learning adalah pembelajaran yang menyuguhkan masalah yang autentik dan bermakna kepada siswa, yang berfungsi sebagai landasan bagi investigasi dan penyelidikan. Problem Based Learning juga dapat meningkatkan keaktifan siswa dalam investigasi baik individu dan kelompok. Siswa akan aktif bertanya dan berani mengemukakan pendapat pada fase penyajian hasil.

Penelitian lain dilakukan oleh Suryandari, dkk (2013), keaktifan dan hasil belajar Matematika siswa kelas V SD Negeri 5 Kutosari, Kebumen dapat ditingkatkan melalui penerapan model Problem Based Learning. Hasil penelitian lain yang dilakukan oleh Walfajri dkk. (2020) yang menyebutkann model pembelajaran PBL dapat meningkatkan kemampuan berpikir krtitis dan hasil belajar. Penelitian didukung dengan penelitian dari Listiani dkk. (2017) dengan hasil penelitiannya yaitu penggunaan model Problem Based learning dapat meningkatkan hasil belajar siswa.

Dari beberapa hasil penelitian diatas penerapan model pembelajaran problem based learning dapat meningkatkan kemampuan menganalisis pada siswa kelas II SD Negeri Somomorodukuh 1. Hal tersebut dibuktikan dengan meningkatnya persentase ketercapaian kemampuan menganalisis siswa pada setiap siklusnya dan meningkatnya hasil belajar kognitif siswa. Dengan demikian, dapat dikatakan model pembelajaran Problem Based Learning dapat digunakan sebagai upaya dalam meningkatkan kemampuan menganalisis pada peserta didik.

\section{SIMPULAN}

Dapat disimpulkan bahwa, penerapan model pembelajaran Problem Based Learning dapat meningkatkan kemampuan menganalisis pada muatan matematika materi kesetaraan berat benda tema merawat hewan dan tumbuhan pada siswa kelas II SD Negeri Somomorodukuh 1 Kecamatan Plupuh. Penilaian yang didapatkan pada saat pelaksanaan pembelajaran pada siklus I adalah 63,15 dengan interpretasi baik. Pada siklus II penilaian meningkat menjadi 77,36 dengan interpretasi baik. Data tersebut menunjukan bahwa pelaksanaan pembelajaran yang dilakukan oleh guru di setiap siklusnya meningkat sesuai dengan yang diharapkan sehingga mampu 
memperbaiki proses dan hasil pembelajaran. Hasil belajar aspek pengetahuan siswa mengalami peningkatan dari siklus I ke siklus II. Penelitian ini menetapkan indikator keberhasilan aspek pengetahuan adalah $85 \%$ dengan kriteria ketuntasan minimal (KKM) 65. Pada siklus I jumlah siswa yang tuntas yaitu 12 siswa dengan persentase $63,15 \%$. Pada siklus II jumlah siswa yang tuntas meningkat menjadi 17 siswa dengan persentase $89,47 \%$. Hal ini berarti bahwa tindakan yang dilakukan sudah melebihi target yang ditentukan yaitu $85 \%$. Model PBL menjadi salah satu alternatif solusi dalam upaya meningkatkan kemampuan menganalisis siswa khususnya jenjang sekolah dasar. Kemampuan menganalisis yang dimiliki oleh siswa dapat digunakan untuk membantu siswa dalam memecahkan permasalahan dalam kehidupan sehari-hari.

\section{DAFTAR PUSTAKA}

Arends, Richard I. (2008). Learning To Teach. Yogyakarta: Pustaka Belajar.

Eismawati, Eka, Henny Dewi Koeswanti, Elvira Hoesein Radia. (2019). Peningkatan hasil belajar matematika melalui model pembelajaran problem based learning (PBL) siswa kelas 4 SD. Jurnal Mercumatika : Jurnal Penelitian Matematika dan Pendidikan Matematika 3(2), 71-78.

Gd. Gunantara. (2014). Penerapan Model Pembelajaran Problem Based Learning Untuk Meningkatkan Kemampuan Pemecahan Masalah Matematika Siswa Kelas V. Jurnal Mimbar PGSD Universitas Pendidikan Ganesha Jurusan PGSD, 2(1).

L. W. Anderson and D. R. Krathwohl (2010) Kerangka Landasan Untuk Pembelajaran, Pengajaran, dan Asasmen. Yogyakarta: Pustaka Pelajar.

Peraturan Menteri Pendidikan dan Kebudayaan Nomor 24 tahun 2016 Tentang Kompetensi Dasar pada kurikulum 2013

R.D.Padmavathy, Mareesh .K. (2013). Effectiveness of Problem Based Learning In Mathematics International Multidisciplinary e-Journal. Research Scholar School of Education Pondicherry University.

Rahmadani, Normala. N. (2017). Peningkatan Aktivitas Belajar Matematika Melalui Pendekatan Problem Based Learning Bagi Siswa Kelasa 4 SD. Scholaria: Jurnal Pendidikan Dan Kebudayaan, 3, 249-250.

Shoimin. (2016). 68 Model Pembelajaran Inovatif dalam Kurikulum 2013. Yogyakarta: Ar Ruzz Media.

Sugiyono (2015) Metode Penelitian Pendidikan (Pendekatan Kuantitatif, Kualitatif, dan R\&D). Bandung: Alfabeta.

Suprihatiningrum, J. (2014). Strategi Pembelajaran Teori dan Aplikasi. Yogyakarta: ArRuz Media

Suryandari, Kartika Chrysti, Rizka Vitasari dan Joharman. (2013). Peningkatan Keaktifan dan Hasil Belajar Matematika melalui Model Problem Based Learning Siswa Kelas V SD Negeri 5 Kutosari. Semarang: Universitas Sebelas Maret.

Suwangsih E., \& Tiurlina. (2018). Model Pembelajaran Matematika. Bandung: Upi Press.

Walfajri, Rida Unnafi dan Hrjono, Nyoto. (2020). Peningkatan Kemampuan Berpikir Kritis dan Hasil Belajar Tematik Muatan IPA Melalui Model Probelm Based Learning Kelas 5 SD. Jurnal Basicedu : 3(1) 16-20. 